\title{
Structural and Electrical Properties of Polysilicon Films Prepared by AIC Process for a Polycrystalline Silicon Solar Cell Seed Layer
}

\author{
Hyejeong Jeong and Seongjae Boo \\ Energy and Applied Optics Research Group, Korea Institute of Industrial Technology (KITECH), 1110-9 Oryong-dong, Buk-gu, \\ Gwangju 500-480, Republic of Korea \\ Correspondence should be addressed to Seongjae Boo, sboo@kitech.re.kr
}

Received 31 August 2011; Accepted 3 December 2011

Academic Editor: Junsin Yi

Copyright (๑) 2012 H. Jeong and S. Boo. This is an open access article distributed under the Creative Commons Attribution License, which permits unrestricted use, distribution, and reproduction in any medium, provided the original work is properly cited.

Polycrystalline silicon ( $\mathrm{pc}-\mathrm{Si}$ ) films are produced by aluminum-induced crystallization (AIC) process for a polycrystalline silicon solar cell seed layer, and the structural and electrical properties of the films are analyzed. The used structure is glass $/ \mathrm{Al} / \mathrm{Al}{ }_{2} \mathrm{O}_{3} / \mathrm{a}-$ $\mathrm{Si}$, and the thickness of $\mathrm{Al}_{2} \mathrm{O}_{3}$ layer was varied from $2 \mathrm{~nm}$ to $20 \mathrm{~nm}$ to investigate the influence of the $\mathrm{Al}_{2} \mathrm{O}_{3}$ layer thickness on the formation of the polycrystalline silicon. The annealing temperature and annealing time were fixed to $400^{\circ} \mathrm{C}$ and 5 hours, respectively, for the AIC process conditions. As a result, it is observed that the average grain size of the pc-Si films is rapidly smaller with increasing the thickness of $\mathrm{Al}_{2} \mathrm{O}_{3}$ layer, whereas the film quality, as defects and Hall mobility, was gradually degraded with only small difference. We obtained the maximum average grain size of $15 \mu \mathrm{m}$ for the pc-Si film with the thickness of $\mathrm{Al}_{2} \mathrm{O}_{3}$ layer of $4 \mathrm{~nm}$. The best resistivity and the Hall mobility was $6.1 \times 10^{-2} \Omega \cdot \mathrm{cm}$ and $90.91 \mathrm{~cm}^{2} / \mathrm{Vs}$, respectively, in the case of $8 \mathrm{~nm}$ thick Al oxide layer.

\section{Introduction}

Crystalline silicon thin-film solar cells are an attractive alternative to the conventional bulk silicon solar cell due to its usability of the low-cost substrates like glass [1]. How to approach to such polycrystalline silicon (pc-Si) thin film solar cell on inexpensive substrate was also well presented $[2]$.

To fabricate such pc-Si thin film solar cells, it is normally needed a good quality seed layer on the substrate. For growing crystalline silicon films on glass as a seed layer, aluminum-induced crystallization (AIC) process of amorphous silicon (a-Si) is a useful method which allows a large size grain on the foreign substrates [3].

Many approaches using AIC method are studied to produce pc-Si thin film as a seed layer on the glass substrate. The structure of a-Si/Al/glass is normally used for the AIC process of the pc-Si seed layer. The influence of the thicknesses and the ratio of $\mathrm{Al}$ and a-Si layer on the formation of the $\mathrm{pc}-\mathrm{Si}$ seed layer was investigated [4], and some studies were on the structure with $\mathrm{Al}$-oxide layer between $\mathrm{Al} / \mathrm{a}-\mathrm{Si}[5,6]$.
Due to the layer exchange during the AIC process with the structure from a-Si/Al/glass to Al/pc-Si/glass, such AIC process for the $\mathrm{pc}$-Si thin film seed layer formation is often called aluminum-induced layer exchange (ALILE) process. The $\mathrm{Al}$-oxide layer, as well as the annealing temperature, is known to play a role in the ALILE process for the formation of the crystal orientation [5]. The preferential crystal orientation depending on the nature of the $\mathrm{Al}$ oxide layer was analytically investigated [7]. The most important properties for the pc-Si seed layer are the large grain and the low defects of the film. The formation of the large-sized grain using AIC was investigated in various ways [8], although the low defects films with small-sized grain showed also a possibility for pc-Si solar cells [9].

The Al-oxide layer between $\mathrm{Al} / \mathrm{a}-\mathrm{Si}$ controls the velocity of the crystallization process and the nucleation density and could lead to the formation of continuous pc-Si film $[5,6]$. It could be necessary to investigate how much the $\mathrm{Al}$-oxide layer could influence the grain size and defects in the film in the ALILE process. 


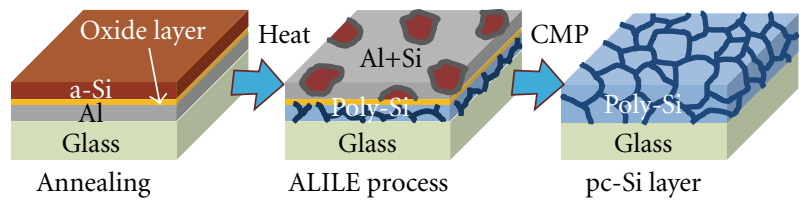

Figure 1: Schematic of the ALILE process.

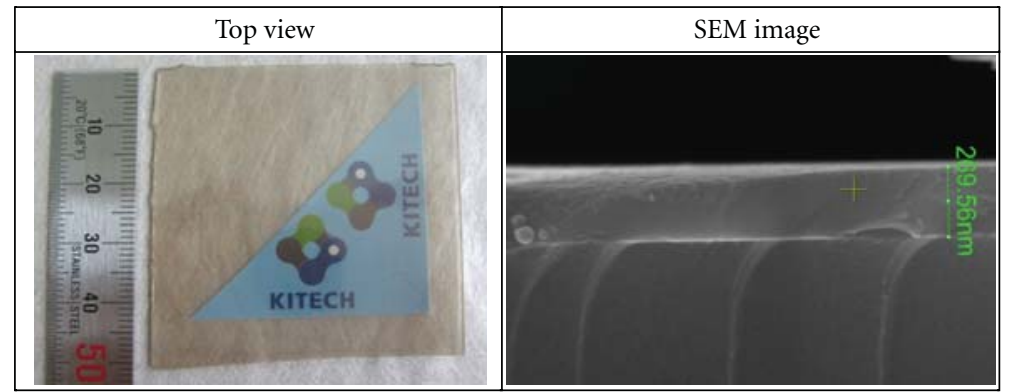

Figure 2: Images of pc-Si film after $\mathrm{Al}$ etching and ultrasonic vibration polishing.

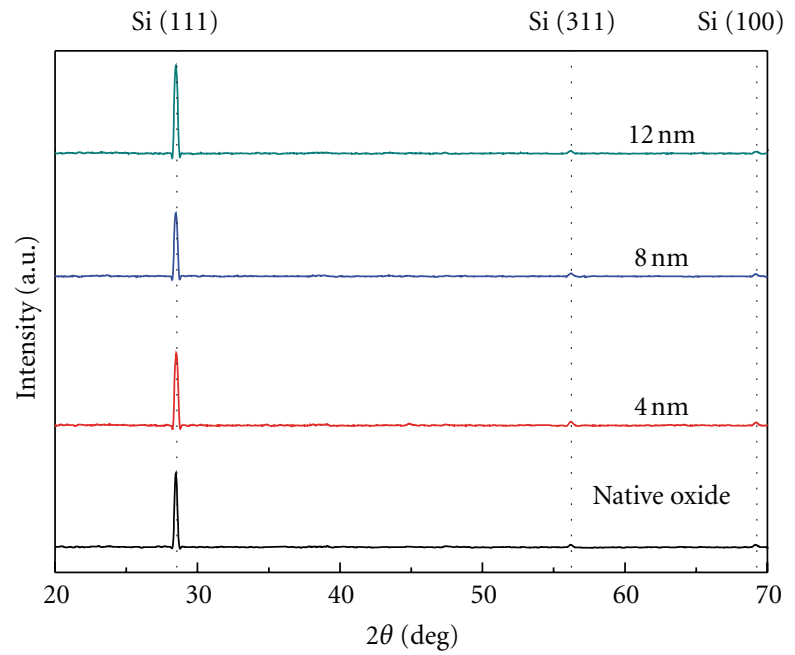

FIGURE 3: XRD spectra of the pc-Si films after etching and polishing.

TABLE 1: Experimental procedure of the ALILE process.

\begin{tabular}{lll}
\hline Deposition condition & Annealing conditions & Removed condition \\
\hline (i) Aluminum layer: $300 \mathrm{~nm}$ using DC sputter & (i) Equipment: tube furnace & $\triangleright$ Al layer: \\
(ii) Al oxide layer: $4 \sim 16 \mathrm{~nm}$ using RF sputter & (ii) Flow gas: $\mathrm{N}_{2}, 20 \mathrm{sccm}$ & Diluted nitric acid, $70^{\circ} \mathrm{C}, 3 \mathrm{~min}$ \\
(iii) a-Si layer: $300 \mathrm{~nm}$ using RF-PECVD & (iii) Pressure: atmosphere & $\triangleright$ Si layer: \\
(iv) Substrate: eagle $2000,0.7 \mathrm{~mm}$ & (iv) Annealing: $400^{\circ} \mathrm{C}, 5$ hours & (i) Amplitude: $60 \%$ \\
& (v) Sample size: $5 \times 5 \mathrm{~cm}$ & (ii) Force: holder only (400 g) \\
\end{tabular}

TABLE 2: Electrical properties of pc-Si films produced by AIC process for various Al oxide layer thicknesses.

\begin{tabular}{lccc}
\hline Sample & Resistivity $[\Omega \cdot \mathrm{cm}]$ & Carrier density $\left[\mathrm{cm}^{-3}\right]$ & Hall ${\mathrm{mobility}\left[\mathrm{cm}^{2} / \mathrm{Vs}\right]}_{87.62}$ \\
\hline Native oxide & $8.2 \times 10^{-2}$ & $8.7 \times 10^{17}$ & 83.54 \\
$4 \mathrm{~nm}$ & $6.1 \times 10^{-2}$ & $1.2 \times 10^{18}$ & 90.91 \\
$8 \mathrm{~nm}$ & $6.1 \times 10^{-2}$ & $1.1 \times 10^{18}$ & 85.12 \\
$12 \mathrm{~nm}$ & $5.7 \times 10^{-2}$ & $1.3 \times 10^{18}$ & 68.78 \\
$16 \mathrm{~nm}$ & $6.2 \times 10^{-2}$ & $1.5 \times 10^{18}$ & 14.14 \\
$20 \mathrm{~nm}$ & $3.1 \times 10^{-1}$ & $1.6 \times 10^{18}$ & \\
\hline
\end{tabular}




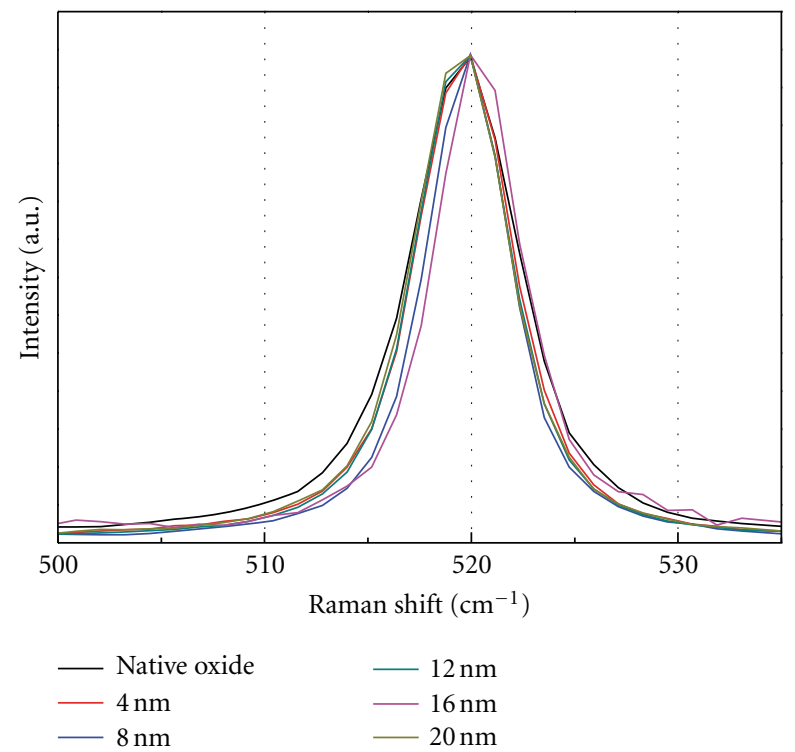

FIGURE 4: Normalized Raman spectrum of poly-Si films for various Al oxide layer thickness.

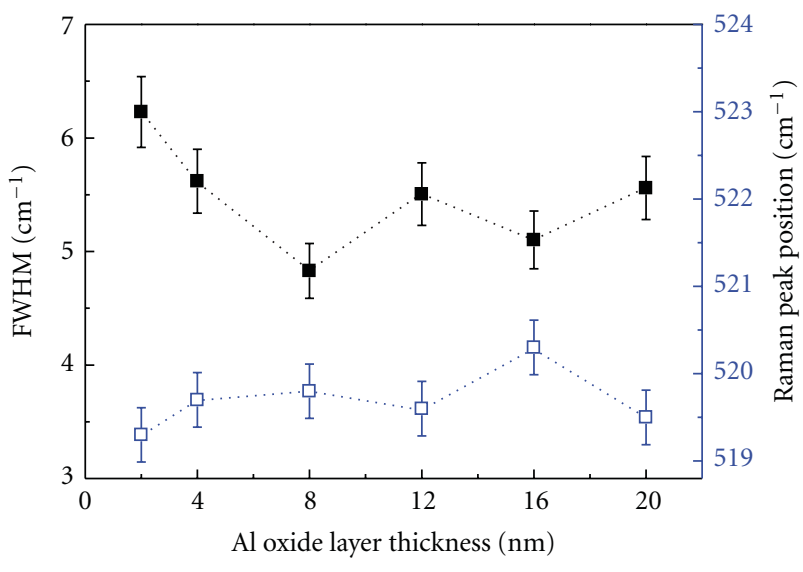

- FWHM

ㅁ. Peak position

FIGURE 5: FWHM and Si peak of poly-Si films as a function of the $\mathrm{Al}$ oxide thickness.

In this work, we investigated the influence of the Al-oxide layer on the pc-Si seed layer, which are formed on the glass substrate by AIC process, depending on the thickness of the $\mathrm{Al}$-oxide layer. And the structural and electrical properties of the poly silicon films are analyzed.

\section{Experimental}

For the AIC experiments, the glass/ $\mathrm{Al} / \mathrm{Al}_{2} \mathrm{O}_{3} / \mathrm{a}-\mathrm{Si}$ structures were prepared with various $\mathrm{Al}_{2} \mathrm{O}_{3}$ film thicknesses from $2 \mathrm{~nm}$ to $20 \mathrm{~nm}$. The Corning Eagle 2000 (strain point of $\left.666^{\circ} \mathrm{C}\right), 0.7 \mathrm{~mm}$ glass with a size of $5 \times 5 \mathrm{~cm}$ was used for the substrate. The Al layers were deposited on the glass substrate by a DC sputter. The thickness of Al layers was fixed to $300 \mathrm{~nm}$. The $\mathrm{Al}$ oxide layers were prepared by a RF magnetron sputter for the thicknesses of $4 \sim 20 \mathrm{~nm}$, whereas the very thin $\mathrm{Al}_{2} \mathrm{O}_{3}$ layer of $\sim 2 \mathrm{~nm}$ was prepared by exposure of the deposited $\mathrm{Al}$ film to air for 2 hours at room temperature and the a-Si films were lastly deposited by PECVD method with the fixed thickness of $300 \mathrm{~nm}$ on the $\mathrm{Al}$ oxide layer.

The AIC process was, then, carried out at the fixed annealing temperature of $400^{\circ} \mathrm{C}$ and for the annealing time of 5 hours in a tube furnace for all samples. After annealing, the resulted upper layer including $\mathrm{Al}$ and $\mathrm{Si}$ islands was removed by diluted nitric acid $\left(\mathrm{H}_{3} \mathrm{PO}_{4}+\right.$ $\mathrm{HNO}_{3}+\mathrm{CH}_{3} \mathrm{COOH}+\mathrm{H}_{2} \mathrm{O}$ ) etching and by ultrasonic vibration polishing with $0.05 \mu \mathrm{m}$ colloidal, sequentially. The AIC procedure is illustrated in Figure 1, and the detailed conditions for the sample preparation are shown in Table 1.

\section{Results and Discussion}

3.1. pc-Si Films after Removing the Al and Si Islands. Al and the $\mathrm{Si}$ islands are successfully removed by $\mathrm{Al}$ etchant etching and by ultrasonic vibration polishing from the AIC processed seed layer structure. The resulted structure is $\mathrm{pc}$-Si/glass and the pc-Si film thickness was about $260 \mathrm{~nm}$ as shown in Figure 2.

The XRD data (Figure 3) shows the crystallinity of the pc-Si film. Only the silicon peaks with (111), (311), and (100) orientations are seen and $\mathrm{Al}$ was clearly removed.

\subsection{Structural Properties of pc-Si Films}

3.2.1. Crystallization. The crystallization of a-Si to pc-Si could be confirmed by Raman analysis. As the Raman spectra of pc-Si films in Figure 4 show, the peak positions for all samples are in the range of $520 \pm 0.4 \mathrm{~cm}^{-1}$. Due to the sharp and symmetric Raman spectra, it is apparent that the crystallization was fully and successfully executed in all the 

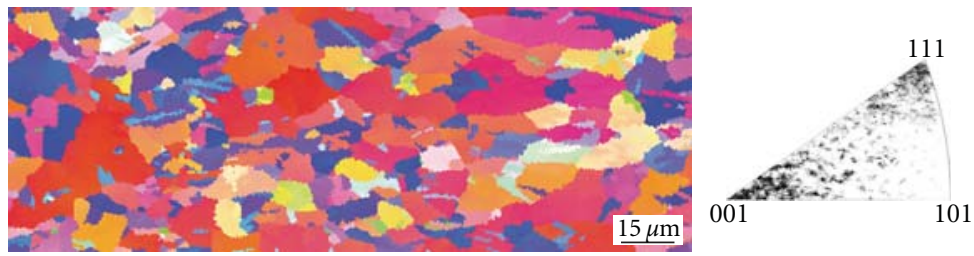

(a) Thickness of $\mathrm{Al}_{2} \mathrm{O}_{3}=2 \mathrm{~nm}$
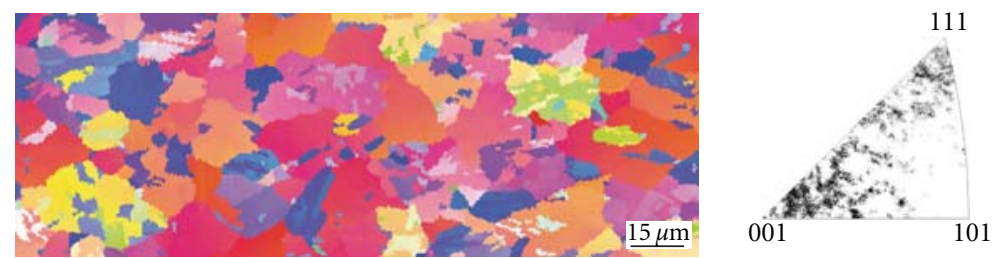

(b) Thickness of $\mathrm{Al}_{2} \mathrm{O}_{3}=4 \mathrm{~nm}$
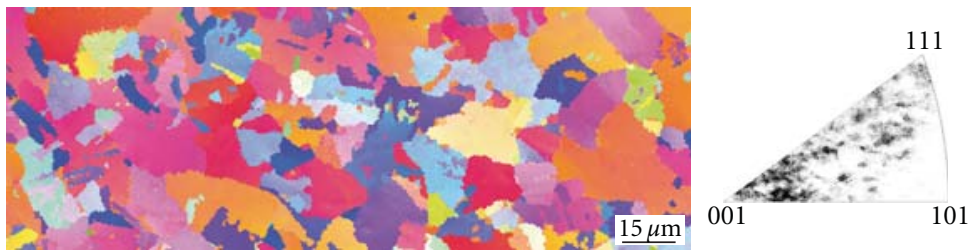

(c) Thickness of $\mathrm{Al}_{2} \mathrm{O}_{3}=8 \mathrm{~nm}$
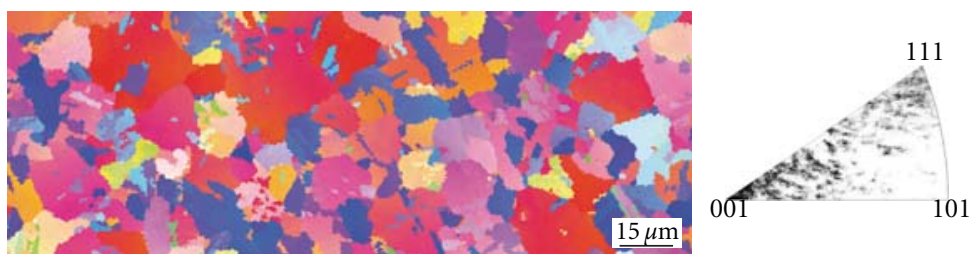

(d) Thickness of $\mathrm{Al}_{2} \mathrm{O}_{3}=12 \mathrm{~nm}$
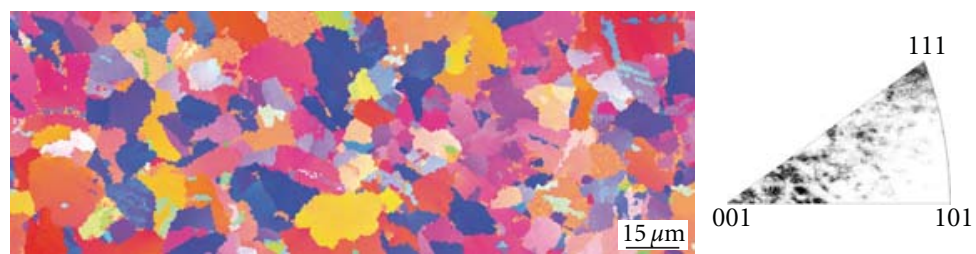

(e) Thickness of $\mathrm{Al}_{2} \mathrm{O}_{3}=16 \mathrm{~nm}$
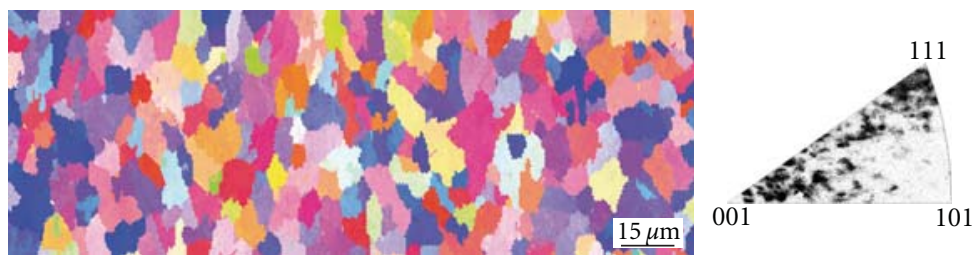

(f) Thickness of $\mathrm{Al}_{2} \mathrm{O}_{3}=20 \mathrm{~nm}$

FIGURE 6: EBSD orientation maps and inverse pole figures of the polysilicon films in normal direction related to various Al oxide thicknesses.

samples. Figure 5 shows the Raman peak position and the full-width at half maximum (FWHM) values, respectively, for the crystalline $\mathrm{Si} \mathrm{TO}$ phonon mode at $520 \mathrm{~cm}^{-1}$. The peak widths are in the range of $4.7 \sim 6.3 \mathrm{~cm}^{-1}$ for the FWHM of all the samples. The difference between their FWHMs is so small that obvious tendency of the $\mathrm{Al}$ oxide layer thickness on the crystallization could not be shown. Nevertheless, the $8 \mathrm{~nm}$ thick sample showed the minimum FWHM value of $4.7 \mathrm{~cm}^{-1}$ with the smallest shift in the peak position, suggesting lowest defects.

3.2.2. Grain Size and Crystal Orientation. Using the Electron backscatter diffraction (EBSD) measurement, the grain size and the crystal orientation of the AIC pc-Si films are analyzed. 


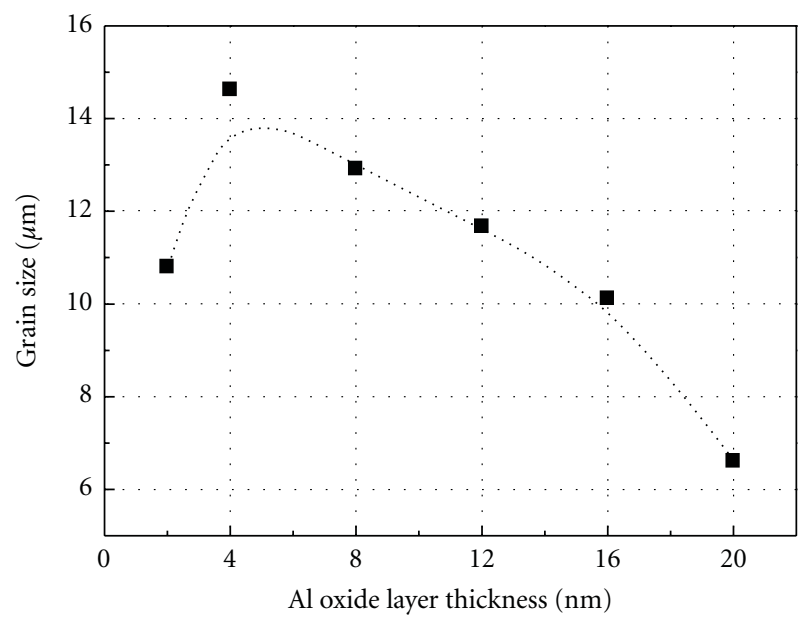

Figure 7: Average grain size extracted from EBSD data of the pc-Si films as a function of $\mathrm{Al}$ oxide layer thickness.

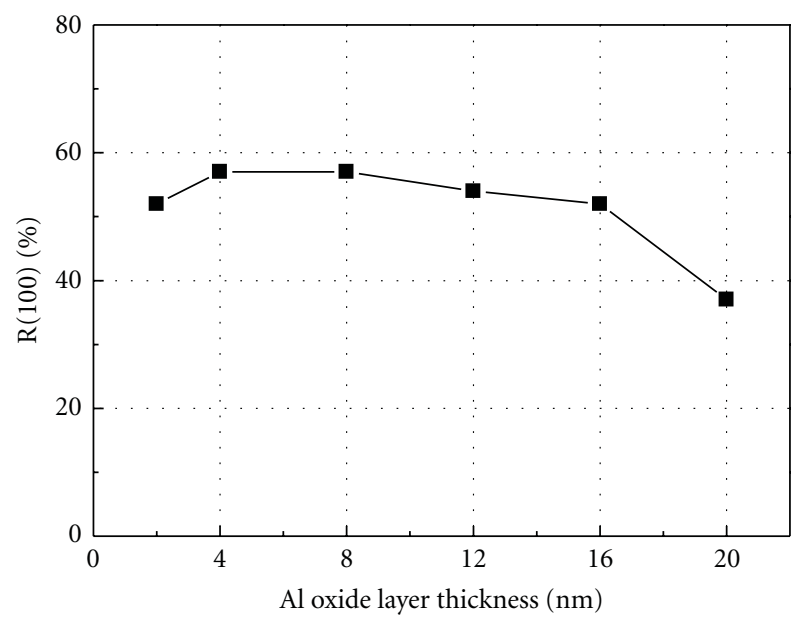

FIGURE 8: Fraction of preferential (100) orientation, R (100) from EBSD data of the pc-Si films, measured after [7] as a function of $\mathrm{Al}$ oxide layer thickness.

Figures 6(a)-6(f) show the EBSD orientation image maps and inverse pole figures for the samples with various $\mathrm{Al}$ oxide layer thicknesses. The colors red, blue, and green represent the (100), (111), and (101) Miller indices, respectively. The trend can be seen that the grain size of the pc-Si film gets smaller with the increased thickness of the $\mathrm{Al}$ oxide layer. It is also apparent that the volume fraction of the preferential (100) orientation in the pc-Si could be more obtained with the decreased thickness of the $\mathrm{Al}$ oxide layer.

In Figures 7 and 8, the calculated average grain size of the pc-Si films and the preferential (100) orientation R (100) after [7] are shown as a function of the $\mathrm{Al}$ oxide layer thickness. The optimum thickness of the $\mathrm{Al}$ oxide layer for the large grain could be in the near of $4 \mathrm{~nm}$ (Figure 7). And the optimum thickness of the $\mathrm{Al}$ oxide layer for the preferential (100) orientation could be in the range of 4 $8 \mathrm{~nm}$ (Figure 8). For the case of $4 \mathrm{~nm}$ sample, we achieved an average grain size of $15 \mu \mathrm{m}$ and the fraction of the preferential (100) orientation more than $58 \%$.

3.2.3. Film Defects. To make extended defects visible, the samples were etched with diluted $\mathrm{HF}$ acid $\left(\mathrm{HF}+\mathrm{K}_{2} \mathrm{Cr}_{2} \mathrm{O}_{7}\right.$ $+\mathrm{H}_{2} \mathrm{O}$ ) at room temperature for 3 seconds and the etch pits were analyzed by scanning electron microscopy (SEM). The quality and defects of the AIC pc-Si films are to see in the SEM images of Figure 9. The grains are well grown with AIC process, and the defects are so small that their boundary is not to be seen in the SEM images for all the samples. The boundaries between the grains could be observed only by EBSD analysis as shown in Figure 6 . As consistent from the results of the Raman and EBSD analyses, the defects were larger and the film quality was lower with the increased thickness of the $\mathrm{Al}$ oxide layer.

3.3. Electrical Properties of pc-Si Films. As electrical properties of pc-Si films, we measured the resistivity, carrier density, and Hall mobility by a Hall effect measurement system.

The measurement results are shown in Figure 10. The Hall mobility was increased a little up to near $8 \mathrm{~nm}$ with the increased thickness of $\mathrm{Al}$ oxide layer and then, rapidly decreased, whereas the carrier density gradually increased. The resistivity was almost unchanged up to $16 \mathrm{~nm}$ and then sharply increased. Such rapid degradation of the electrical properties for the relatively thick $\mathrm{Al}$ oxide layer $(>16 \mathrm{~nm})$ could be mainly affected from the defects of the film, that is, incomplete crystallization of the AIC process. But the small property changes for the relatively thin $\mathrm{Al}$ oxide layers $(<16 \mathrm{~nm})$ may be resulted from the influence of the $\mathrm{Al}$ oxide layer on the crystallization.

Near $8 \mathrm{~nm}$ of $\mathrm{Al}$ oxide layer thickness could be the optimum for the electrical properties. In this case, the resistivity, the carrier density, and the Hall mobility were $6.1 \times$ $10^{-2} \Omega \cdot \mathrm{cm}, 1.1 \times 10^{18} \mathrm{~cm}^{-3}$, and $90.91 \mathrm{~cm}^{2} / \mathrm{Vs}$, respectively.

Due to the remained Al content in the pc-Si film by the AIC process, all films show a p-type poly silicon property. The electrical properties of the pc-Si films are shown in Table 2 .

\section{Conclusion}

In this work, we investigated the structural and electrical properties of the pc-Si films produced by AIC process, depending on the thickness of the $\mathrm{Al}$ oxide interlayer between $\mathrm{Al} / \mathrm{a}-\mathrm{Si}$ layers.

In conclusion, we showed the influence of the thickness of the $\mathrm{Al}$ oxide interlayer between $\mathrm{Al} / \mathrm{a}-\mathrm{Si}$ layers on the properties of the AIC pc-Si film, like the grain size, the crystal orientation, and the film defects. The tendency of the dependence of the structural properties on the oxide layer was consistent with the case of the electrical properties. But the dependence of the structural properties was slightly more sensitive than the case of the electrical properties. In our experimental conditions, the optimum value of the $\mathrm{Al}$ oxide thickness could be in the range of $4 \sim 8 \mathrm{~nm}$. For the sample of $4 \mathrm{~nm}$ thick $\mathrm{Al}$ oxide layer, we achieved the average grain size 


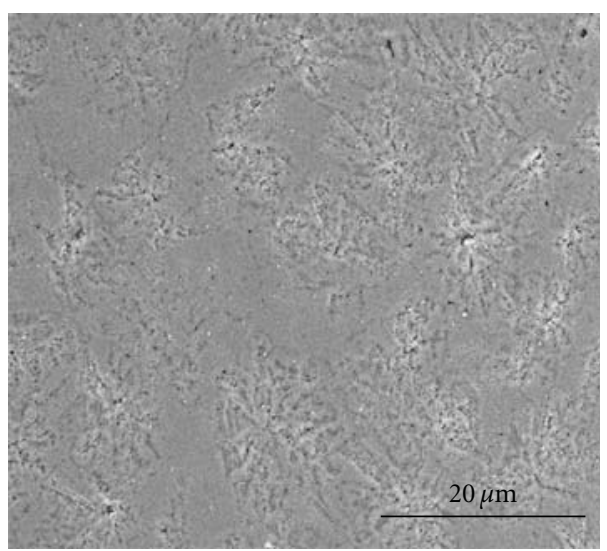

(a) Thickness of $\mathrm{Al}_{2} \mathrm{O}_{3}=4 \mathrm{~nm}$

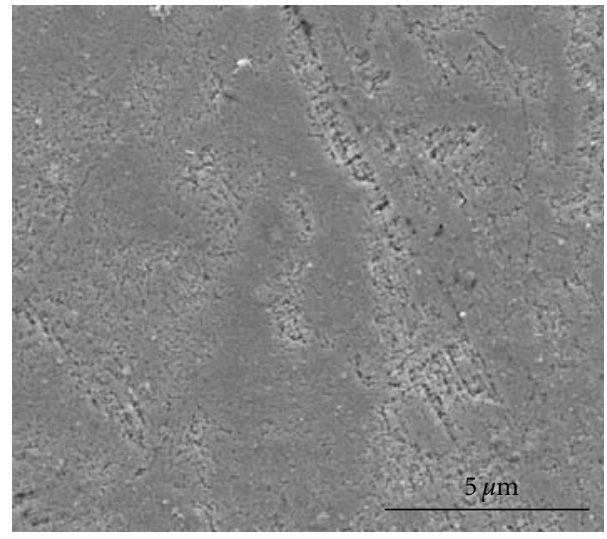

(c) Thickness of $\mathrm{Al}_{2} \mathrm{O}_{3}=16 \mathrm{~nm}$

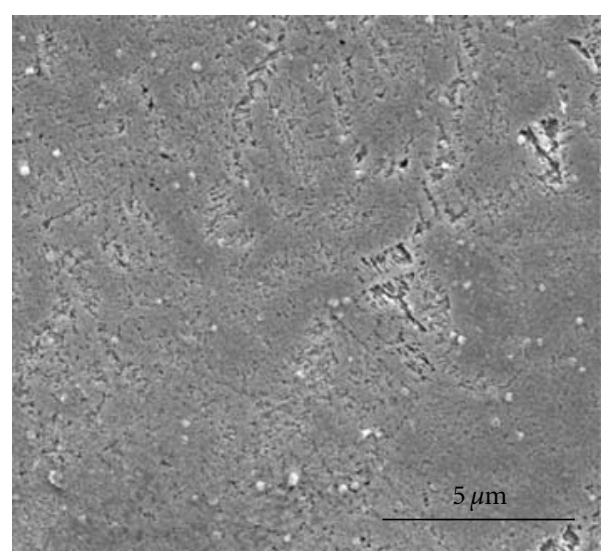

(b) Thickness of $\mathrm{Al}_{2} \mathrm{O}_{3}=12 \mathrm{~nm}$

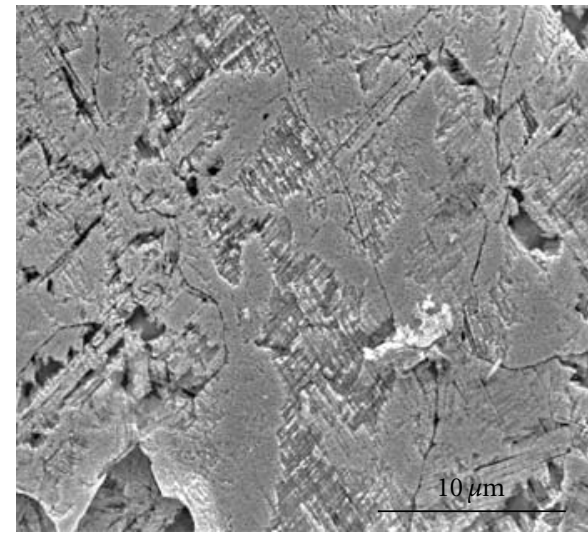

(d) Thickness of $\mathrm{Al}_{2} \mathrm{O}_{3}=20 \mathrm{~nm}$

FIGURE 9: SEM images of pc-Si films for samples with various $\mathrm{Al}$ oxide layer thicknesses.

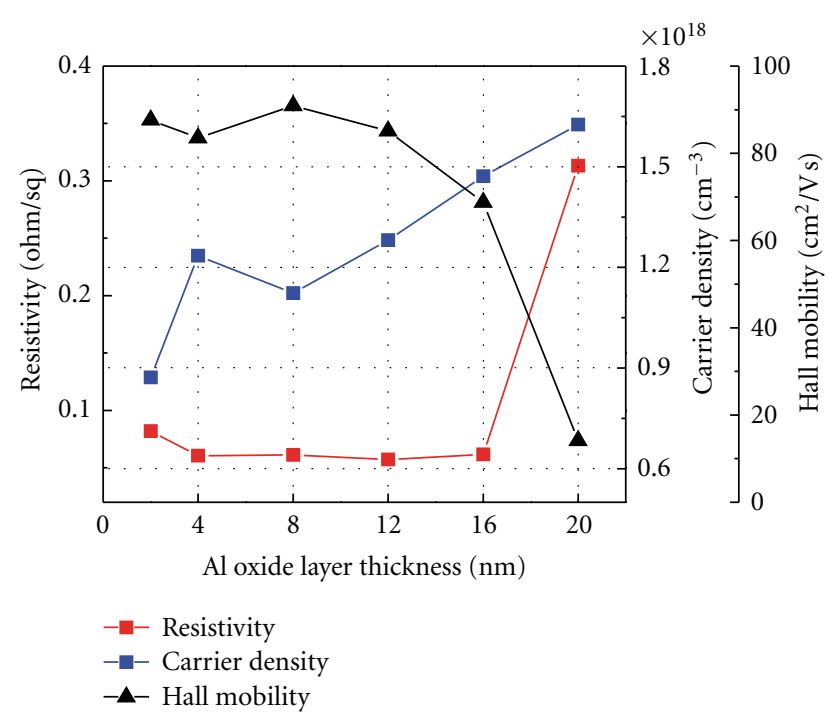

FIGURE 10: Resistivity, Hall mobility, and carrier density of the pc-Si films as a function of difference $\mathrm{Al}$ oxide layer thickness.

of $15 \mu \mathrm{m}$ and the preferential $<100>$ orientation, $\mathrm{R}(100)$, of more than $58 \%$. The Hall mobility and resistivity were
$6.1 \times 10^{-2} \mathrm{~cm}, 90.91 \mathrm{~cm}^{2} / \mathrm{Vs}$, respectively, for the $8 \mathrm{~nm}$ thick $\mathrm{Al}$ oxide layer as best case.

\section{References}

[1] K. Yamamoto, M. Yoshimi, Y. Tawada, Y. Okamoto, A. Nakajima, and S. Igari, "Thin-film poly-Si solar cells on glass substrate fabricated at low temperature," Applied Physics A, vol. 69, no. 2, pp. 179-185, 1999.

[2] W. Fuhs, S. Gall, B. Rau, M. Schmidt, and J. Schneider, "A novel route to a polycrystalline silicon thin-film solar cell," Solar Energy, vol. 77, no. 6, pp. 961-968, 2004.

[3] O. Nast and S. R. Wenham, "Elucidation of the layer exchange mechanism in the formation of polycrystalline silicon by aluminum-induced crystallization," Journal of Applied Physics, vol. 88, no. 1, pp. 124-132, 2000.

[4] I. Sieber, R. Schneider, I. Doerfel, P. Schubert-Bischoff, S. Gall, and W. Fuhs, "Preparation of thin polycrystalline silicon films on glass by aluminium-induced crystallisation-an electron microscopy study," Thin Solid Films, vol. 427, no. 1-2, pp. 298302, 2003.

[5] O. Nast and A. J. Hartmann, "Influence of interface and Al structure on layer exchange during aluminum-induced crystallization of amorphous silicon," Journal of Applied Physics, vol. 88, no. 2, pp. 716-724, 2000. 
[6] S. Gall, J. Schneider, M. Muske, I. Sieber, O. Nast, and W. Fuhs, "Poly-si seeding layers by aluminum-induced crystallization," in Proceeding of the PV in Europe, pp. 87-90, Rome, Italy, 2002.

[7] J. Schneider, A. Sarikov, J. Klein et al., "A simple model explaining the preferential (100) orientation of silicon thin films made by aluminum-induced layer exchange," Journal of Crystal Growth, vol. 287, no. 2, pp. 423-427, 2006.

[8] S. Gall, M. Muske, I. Sieber, O. Nast, and W. Fuhs, "Aluminuminduced crystallization of amorphous silicon," Journal of NonCrystalline Solids, vol. 299-302, no. 2, pp. 741-745, 2002.

[9] L. Carnel, I. Gordon, D. van Gestel, G. Beaucarne, and J. Poortmans, "Efficient solar cells based on fine-grained polysilicon," Thin Solid Films, vol. 516, no. 20, pp. 6839-6843, 2008. 


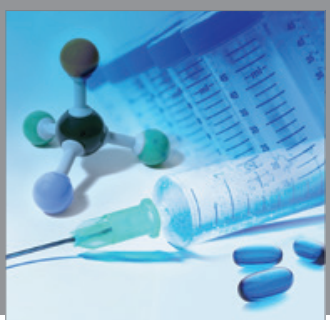

International Journal of

Medicinal Chemistry

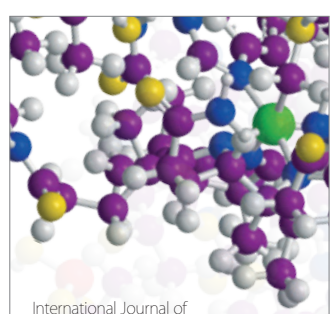

Carbohydrate Chemistry

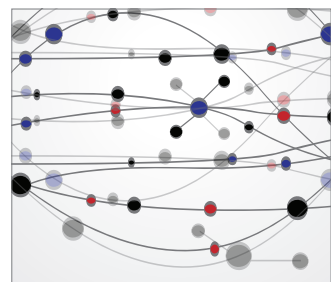

The Scientific World Journal
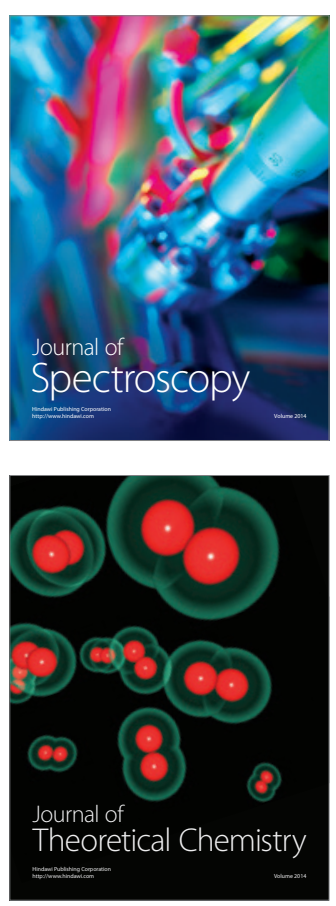
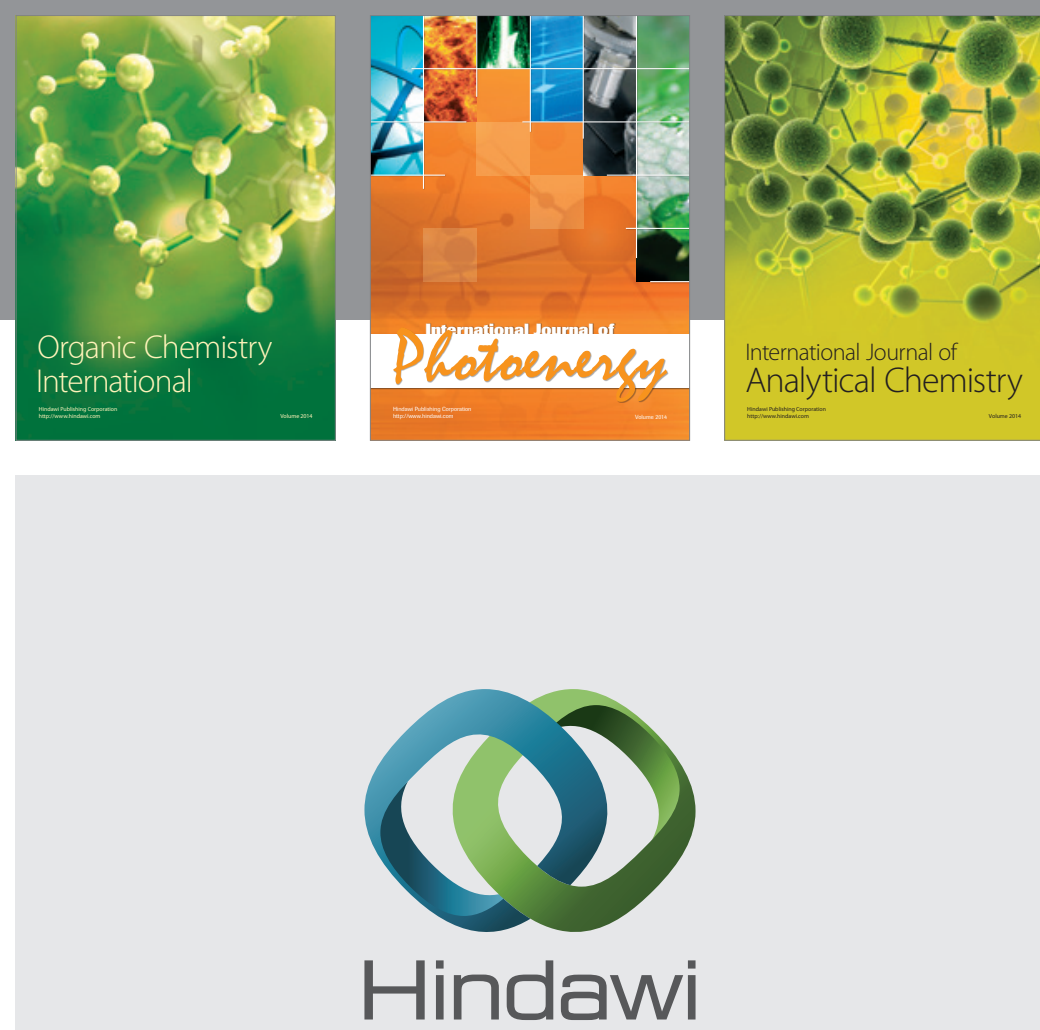

Submit your manuscripts at

http://www.hindawi.com
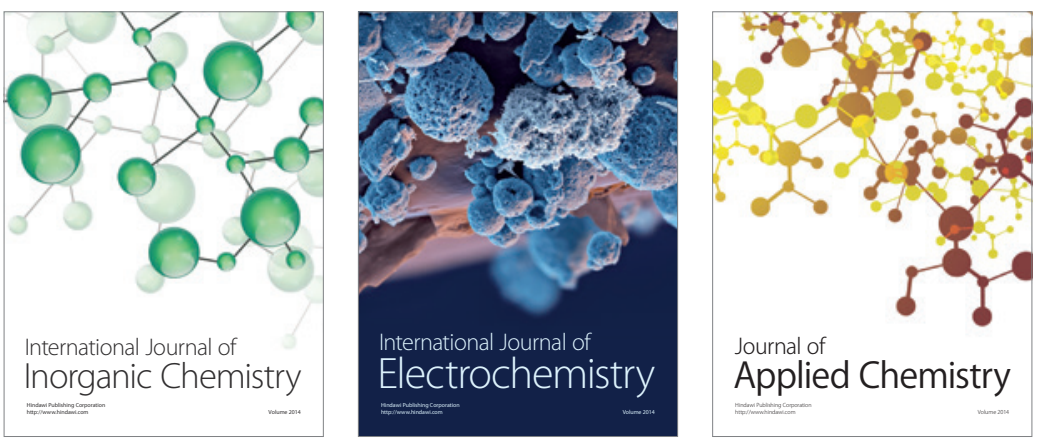

Journal of

Applied Chemistry
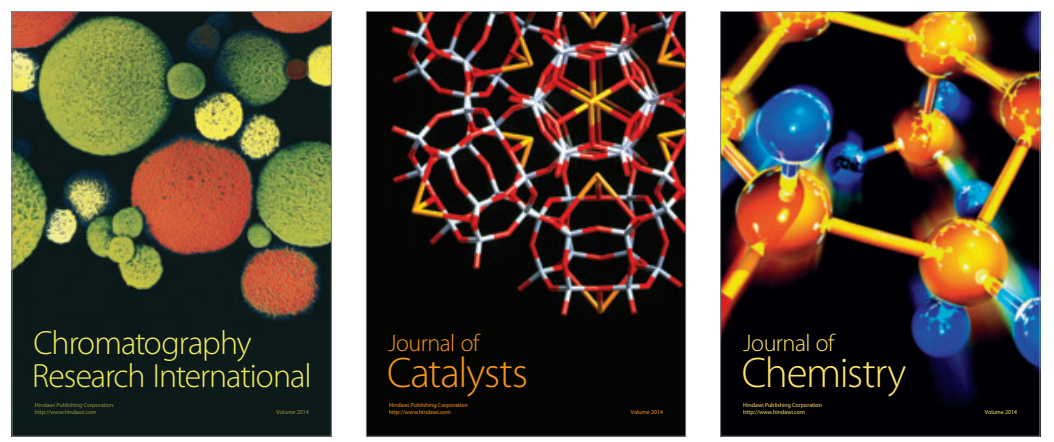
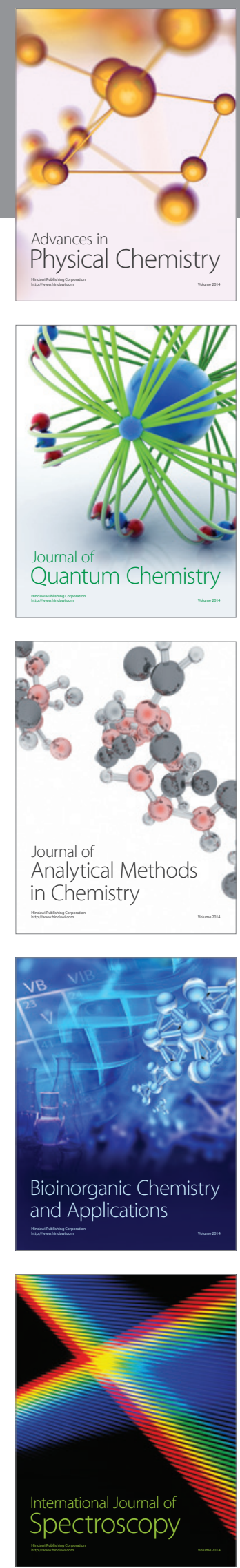